\title{
Precision of bacterioplankton biomass determination: a comparison of two fluorescent dyes, and of allometric and linear volume-to- carbon conversion factors
}

\author{
Thomas Posch ${ }^{1, *}$, Maria Loferer-Krößbacher ${ }^{1}$, Guang Gao ${ }^{2}$, Albin Alfreider ${ }^{3}$, \\ Jakob Pernthaler ${ }^{4}$, Roland Psenner ${ }^{1}$ \\ ${ }^{1}$ Institute of Zoology and Limnology, University of Innsbruck, Technikerstr. 25, 6020 Innsbruck, Austria \\ ${ }^{2}$ Nanjing Institute of Geography and Limnology, Chinese Academy of Sciences, 73 East Beijing Road, Nanjing 210008, China \\ ${ }^{3}$ UFZ Center for Environmental Research, Department of Environmental Microbiology, Permoserstr. 15, 04318 Leipzig, Germany \\ ${ }^{4}$ Max-Planck Institute for Marine Microbiology, Celsiusstr. 1, 28359 Bremen, Germany
}

\begin{abstract}
We studied the influence of methodology on the variability of bacterial direct counts and biomass estimates. Two frequently used fluorochromes, 4,6-diamidino-2-phenylindole (DAPI) and 3,6-bis(dimethylamino)acridine (acridine orange [AO]), were applied to determine bacterial abundances and sizes along a vertical profile in a oligo-mesotrophic freshwater lake (Piburger See, Austria). Only $90 \pm 11 \%$ of AO stained bacteria were detected with the fluorochrome DAPI. On average, DAPI stained cells were half as large ( $48 \pm 11 \%$ of mean cell volume) as cells stained with AO. The observed discrepancies in abundance and cell volumes were significantly related to community DNA synthesis rates, as suggested by lower differences at higher uptake rates of $\left[{ }^{3} \mathrm{H}\right]$ thymidine. In addition, a decrease in the relative DNA content cell ${ }^{-1}$ with increasing cell size was found in the bacterioplankton assemblage. Considering the staining properties of the 2 dyes, this may partially account for the observed differences in mean cell sizes. We summarized and evaluated most linear and allometric volume-to-carbon conversion factors published during the past 2 decades. Total bacterial biomass was estimated by applying several of these conversion factors to data sets determined from DAPI and AO stained preparations. Depending on the dye and conversion factor, bacterial biomass,

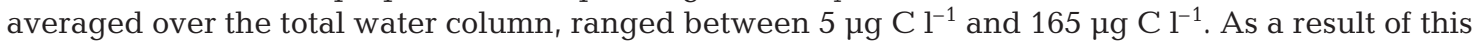
comparison we recommend the use of allometric conversion formulae specifically elaborated for a particular dye, i.e., $C C=218 \times \mathrm{V}^{0.86}$ (Loferer-Krößbacher et al. 1998) for DAPI stained bacteria and CC $=120 \times \mathrm{V}^{0.72}$ (Simon \& Azam 1989, recalculated by Norland 1993) for AO stained cells (where CC is cellular carbon content $[\mathrm{fg} \mathrm{C}]$, and $\mathrm{V}$ is bacterial volume $\left.\left[\mu^{3}\right]\right)$. In addition, these 2 formulae produced biomass estimates closest to the median values of estimates by all the investigated conversion factors.
\end{abstract}

KEY WORDS: Bacterial size - Epifluorescence direct counting · Volume-to-carbon conversion Resale or republication not permitted without written consent of the publisher

\section{INTRODUCTION}

One prerequisite for analyses of carbon fluxes in aquatic microbial food webs is the availability of reliable, exact methods to quantify dissolved and particulate carbon. In most studies bacterial and protistan car-

*E-mail: thomas.posch@uibk.ac.at bon is quantified by a combination of cell counting, cell sizing and the use of conversion factors based on cell volume. The commonly used procedure for the determination of total bacterial biomass (e.g., in $\mu \mathrm{g} \mathrm{Cl}^{-1}$ ) in aquatic systems is based on staining of samples with a fluorescent dye such as 4,6-diamidino-2-phenylindole (DAPI) or 3,6-bis(dimethylamino)acridine (acridine orange $[\mathrm{AO}])$, the epifluorescence direct counting 
method, sizing of bacterial cells on photomicrographs or through image analysis, and finally the calculation of cellular carbon content (CC) by applying linear or allometric conversion factors (Hobbie et al. 1977, Porter \& Feig 1980, Sieracki et al. 1985, Bjørnsen 1986, Fry 1990, Kepner \& Pratt 1994, Massana et al. 1997). Although these methods are now widely accepted basic tools in aquatic microbial ecology, they are by no means standardized and it is still unclear which fluorescent stains and conversion factors are most appropriate for various purposes and systems. In this study we looked for differences in the determination of bacterial abundance and cell volumes by using the 2 most commonly applied dyes (DAPI, AO). This comparison was stimulated by the results of Sieracki \& Viles (1992) and Suzuki et al. (1993) showing that staining with DAPI resulted in lower numbers and smaller sizes of stained particles than staining with AO. Two potential reasons for discrepancies were explored: we compared the ratio of DNA to cell size of natural assemblages of bacteria, and we examined the relation between bacterial secondary production and the properties of the 2 dyes. We then applied several published conversion factors to calculate bacterial carbon on the basis of cell volume. While some formulae gave similar results, we also found extreme variability (larger than 1 order of magnitude) when different stains and carbon conversion factors were used.

\section{MATERIAL AND METHODS}

We took a vertical sampling profile (Fig. 1) over the deepest point (24.6 m) of the oligo-mesotrophic Piburger

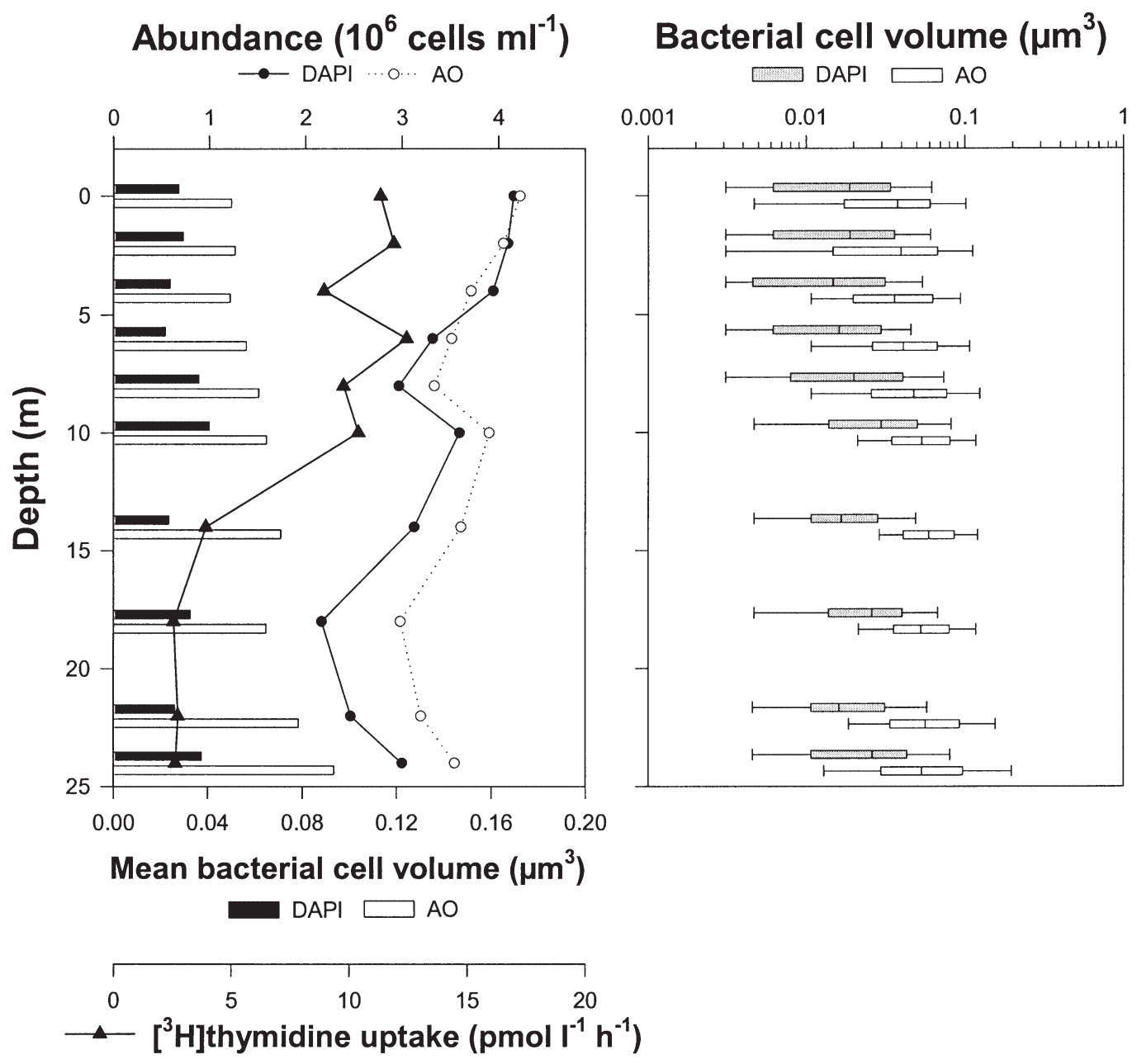

Fig. 1. Vertical distribution of bacterial abundance and mean cell volumes in Piburger See (Tyrol, Austria) determined from DAPI and acridine orange (AO) stained samples (left panel). $\left[{ }^{3} \mathrm{H}\right]$ thymidine incorporation rates are shown along the vertical profile (left panel). Box whisker plots of bacterial cell volumes are shown along the vertical sampling profile (right panel). Volumes were measured by image analysis on DAPI and AO stained sub-samples. Boxes range between the 25th and the 75th percentiles of a data set. The line in the box represents the median, and whiskers indicate the 10th and the 90th percentiles 
See (Tyrol, Austria) in August 1995. Detailed data on biotic and abiotic parameters of this lake have been published by Pechlaner (1979) and Sommaruga \& Psenner (1995). Samples were fixed with $0.2 \mu \mathrm{m}$ pre-filtered formaldehyde ( 2 to $3 \%$ final conc.), stored at $4{ }^{\circ} \mathrm{C}$ in the dark and processed within 3 wk. For each sampling depth one sub-sample was stained with DAPI ( $5 \mathrm{\mu g} \mathrm{ml}^{-1}$ final conc. for $7 \mathrm{~min})$ and a second one with AO (12 $\mu \mathrm{g}$ $\mathrm{ml}^{-1}$ final conc. for $2 \mathrm{~min}$ ). Sub-samples were filtered onto black $0.2 \mu \mathrm{m}$ pore sized polycarbonate filters (Osmonics Laboratory Products, MN, USA) and embedded in low-fluorescent immersion oil (Cargille type A, Cargille Laboratories, Inc., NJ, USA). Ten to 15 microscopical fields sample ${ }^{-1}$ were inspected, which corresponded to 400 to 800 counted bacteria. From theoretical considerations and our own experience we estimate a coefficient of variation between 3.5 and $5 \%$ of the mean value if 400 to 800 bacteria are counted sample ${ }^{-1}$. We used a Zeiss Axiovert 135 (Zeiss, Oberkochen, Germany) for counting and a Zeiss Axioplan epifluorescence microscope for recording images, equipped with a HBO 50W and a HBO 103W mercury lamp (Osram, München, Germany), respectively. Both microscopes had an optovar for additional magnification (up to 2.5 $\times$ ), and filter sets for UV, blue and green excitation (Zeiss filter sets 01,09 and 14). Fifteen to 20 images $(524 \times 752$ pixels) of each preparation were recorded with the image analysis system LUCIA_D (Laboratory Imaging, s.r.o., Prague, Czech Republic) connected to a SIT television camera (Hamamatsu C2400-08, Hamamatsu, Hamamatsu City, Japan). At a magnification of $200 \times$ a pixel corresponded to $0.085 \mu \mathrm{m}$ and had 8 bits of information (256 possible gray values). Four images of the same microscopical field were averaged to reduce electronic noise. All details about image processing, i.e., gray transformation, edge finding, measured cell dimensions and calculation of bacterial cell volumes, were published by Posch et al. (1997). Between 600 and 1100 cells were measured for each sample and staining. Total bacterial biovolume $\left(\mathrm{mm}^{3} \mathrm{l}^{-1}\right)$ was calculated as the product of abundance (cells ${ }^{-1}$ ) and mean bacterial cell volume $\left(\mu \mathrm{m}^{3}\right)$. We collected linear and allometric formulae from the literature to estimate bacterial CC $\left(\mathrm{fg} \mathrm{C} \mathrm{cell}^{-1}\right)$ from cell volume. Total bacterial biomass $\left(\mu \mathrm{C} \mathrm{Cl}^{-1}\right)$ was determined from bacterial abundance multiplied by CC. Bacterial production was measured through uptake rates of $\left[{ }^{3} \mathrm{H}\right]$ thymidine (Fuhrman \& Azam 1982). Normal distribution of data was checked by a Kolmogorov-Smirnov test. Relations between original data were tested by Pearson product moment correlation analysis. Significant differences between treatments (DAPI, AO) were tested by paired $t$-tests. All statistical analyses were done with the software Statistica (StatSoft Inc., OK, USA). The quantification of DNA and cell mass is described in detail in Loferer-Krößbacher et al. $(1998,1999)$. It is based on densitometric image analysis techniques in both epifluorescence microscopy (DNA and cell size) and TEM (cell mass and cell size).

\section{RESULTS AND DISCUSSION}

\section{Determination of bacterial abundance and cell volume}

Staining with DAPI resulted in the detection of $90 \pm$ $11 \%$ of particles visualized by AO (Fig. 1, Table 1). We obtained a very similar pattern of particle abundances along the vertical profile independently of the stain used, and numbers were highly significantly correlated $(\mathrm{r}=0.95, \mathrm{p}<0.001)$. However, abundances based on DAPI and AO stained samples were significantly different $(t=-3.03, \mathrm{p}=0.01)$. Differences between cell numbers increased slightly along the depth profile and the fraction of AO stained particles that was also visualized by DAPI was positively correlated

Table 1. Comparison between the DAPI and AO staining methods for determination of bacterial parameters in various aquatic systems (observed and published data). Comparisons are calculated as means \pm 1 SD. References: (1) this study, (2) Porter \& Feig

(1980), (3) Suzuki et al. (1993), (4) Sieracki \& Viles (1992). nd: not determined or not defined; No diff: no difference observed

\begin{tabular}{|c|c|c|c|c|c|c|}
\hline \multirow[t]{2}{*}{ Sampling site } & \multicolumn{2}{|c|}{$\begin{array}{c}\text { Dye concentration } \\
\left(\mu \mathrm{gl} \mathrm{m}^{-1}\right)\end{array}$} & \multirow{2}{*}{$\begin{array}{c}\text { Bacterial } \\
\text { abundance } \\
\text { DAPI/AO (\%) }\end{array}$} & \multirow{2}{*}{$\begin{array}{c}\text { Mean cell } \\
\text { volume } \\
\text { DAPI/AO (\%) }\end{array}$} & \multirow{2}{*}{$\begin{array}{c}\text { Bacterial } \\
\text { biovolume } \\
\text { DAPI/AO (\%) }\end{array}$} & \multirow[t]{2}{*}{ Reference } \\
\hline & DAPI & $\mathrm{AO}$ & & & & \\
\hline Piburger See, Austria & 5 & 12 & $90 \pm 11$ & $48 \pm 11$ & $44 \pm 12$ & (1) \\
\hline Lake Oglethorpe, USA & 0.01 & 10 & 98 & nd & nd & $(2)$ \\
\hline South Slough estuary, USA & 25 & 50 & $74 \pm 8$ & $61 \pm 14$ & $47 \pm 11$ & (3) \\
\hline Oregon coast, USA & 25 & 50 & $67 \pm 9$ & $57 \pm 14$ & $38 \pm 8$ & (3) \\
\hline \multicolumn{3}{|c|}{ Chesapeake Bay (USA), Sargasso Sea } & & & & $(4)$ \\
\hline Bacteria & 5 & nd & No diff & 92 & No diff & \\
\hline Small dim particles & 5 & nd & $46 \pm 37$ & No diff & $58 \pm 54$ & \\
\hline
\end{tabular}


with incorporation rates of $\left[{ }^{3} \mathrm{H}\right]$ thymidine $(\mathrm{r}=0.8$, $\mathrm{p}<0.01$ ). As DAPI preferentially binds DNA we hypothesize that bacteria with higher DNA synthesis rates are better visualized with this dye and consequently the difference from the number of AO stained cells becomes smaller. Growing bacterial cells may contain more than 1 genome copy, and higher DAPI staining intensities are found in logarithmically growing bacteria (e.g., Loferer-Krößbacher et al. 1999). It has also been reported that the relative abundance of DNArich bacteria in marine samples is related to bacterial activity (Gasol et al. 1999).

Published data on differences in the determination of bacterial abundance using DAPI and AO are scarce and inconclusive (Table 1). Suzuki et al. (1993) found significantly lower bacterial numbers when using DAPI than when using AO. Sieracki \& Viles (1992) determined the same bacterial numbers with both dyes, but the abundances of DAPI stained so-called 'small dim particles' (sub-micrometer particles) were on average only $46 \pm 37 \%$ of values obtained by using AO (Table 1). This differentiation between bacteria and small dim particles points to another insecurity in interpreting direct counts obtained from DAPI and AO stained samples. It has been argued that the bulk of particles visualized by each dye can be split into nucleoid-containing bacteria, 'ghosts' (non-nucleoidcontaining bacteria, Zweifel \& Hagström 1995), bacteria with high or low DNA content (Gasol et al. 1999) and sub-micrometer detritus (Koike et al. 1990, Sieracki \& Viles 1992). Additionally, large aquatic viruses or virus-like-particles can overlap in size with the smallest size class $(<0.4 \mu \mathrm{m})$ of bacteria (Sommaruga et al. 1995). Therefore, by using only epifluorescence microscopy for bacterial counts it is not possible to distinguish between viruses and small coccoid bacteria. However, there is evidence from the marine plankton that most DAPI stained particles $(>80 \%)$ collected on filters with $0.2 \mu \mathrm{m}$ pore size are not of viral origin (Karner et al. 2001). In this study we attempted no further differentiation but rather compared the whole sum of DAPI stained versus AO stained particles. An obvious advantage of the DAPI method is the clear distinction between autofluorescent (pigment containing) and non-photosynthetic cells. One major drawback of DAPI, on the other hand, lies in the large scatter in the ratio of DNA to cell mass (Fig. 2, see below) and in the decreasing relative DNA content of larger bacteria. This may result in a general underestimation of true cell dimensions of the fraction of the bacterioplankton that is larger.

Mean cell volumes of DAPI stained cells were significantly smaller than those determined by AO staining, on average $48 \pm 11 \%$ (range 33 to 66$)(t=-8.46, \mathrm{p}<$ 0.001) (Fig. 1, Table 1). There was no significant corre-

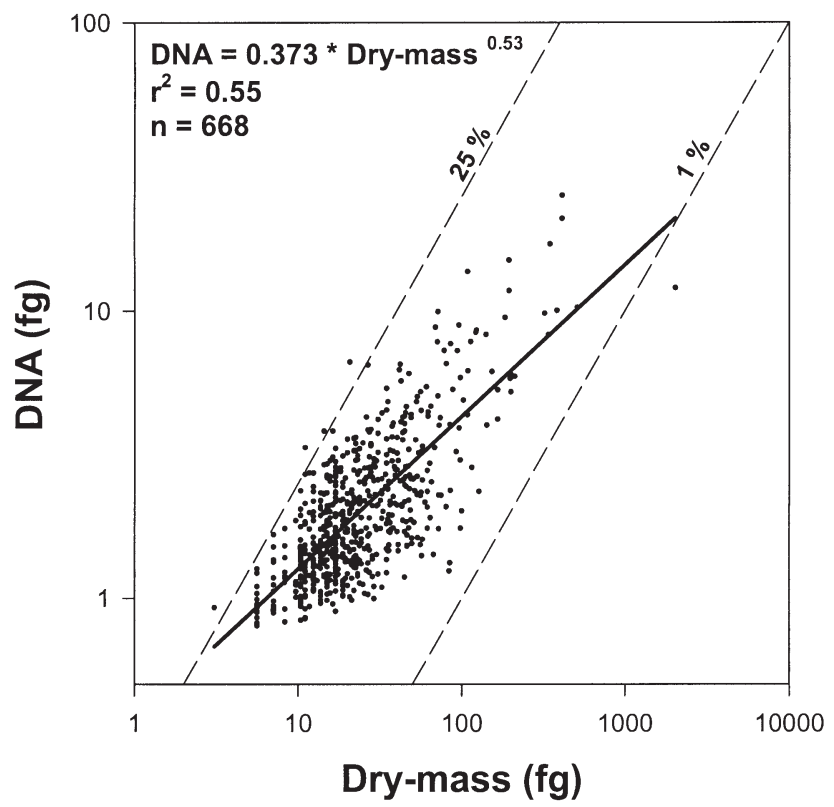

Fig. 2. Allometric relation between DNA content and dry mass of pelagic bacteria from Piburger See (Tyrol, Austria). Samples were stained with DAPI and cell volumes and optical brightness were measured for 668 single cells. Conversion factors to calculate bacterial dry mass and DNA content were published in Loferer-Krößbacher et al. $(1998,1999)$

lation between the 2 data-sets $(r=0.37, p=0.29)$. We found a significant negative correlation between the difference of cell volumes determined by DAPI or AO and the incorporation rates of $\left[{ }^{3} \mathrm{H}\right]$ thymidine $(\mathrm{r}=-0.79$, $p<0.01)$. This implies that at higher bacterial activity cell volumes of DAPI and AO stained cells become more similar. Size distributions of DAPI stained bacteria along the depth profile differed remarkably from the patterns obtained by AO staining (Fig. 1). For example, at the surface $(0 \mathrm{~m}) 50 \%$ of DAPI stained cells were found in a size range of 0.006 to $0.03 \mu^{3}$ whereas $50 \%$ of AO stained bacteria were between 0.02 and $0.06 \mu^{3}$ (Fig. 1). These differences, for example, strongly affect conclusions about the relative importance of the different compartments of microbial food webs or the relation between cell size and mortality inflicted by selective predation (Pernthaler et al. 1996). By using DAPI staining, the total bacterial biovolume $\left(\mathrm{mm}^{3} \mathrm{l}^{-1}\right)$ was on average only $44 \pm 12 \%$ (range 26 to 58) of that determined by AO staining (Table 1).

\section{Comparison of linear and allometric conversion factors}

To estimate total bacterial biomass $\left(\mu \mathrm{g} \mathrm{C} \mathrm{l}^{-1}\right)$, a conversion of bacterial cell volume to $\mathrm{CC}$ is required. We summarized published data on allometric conversion 


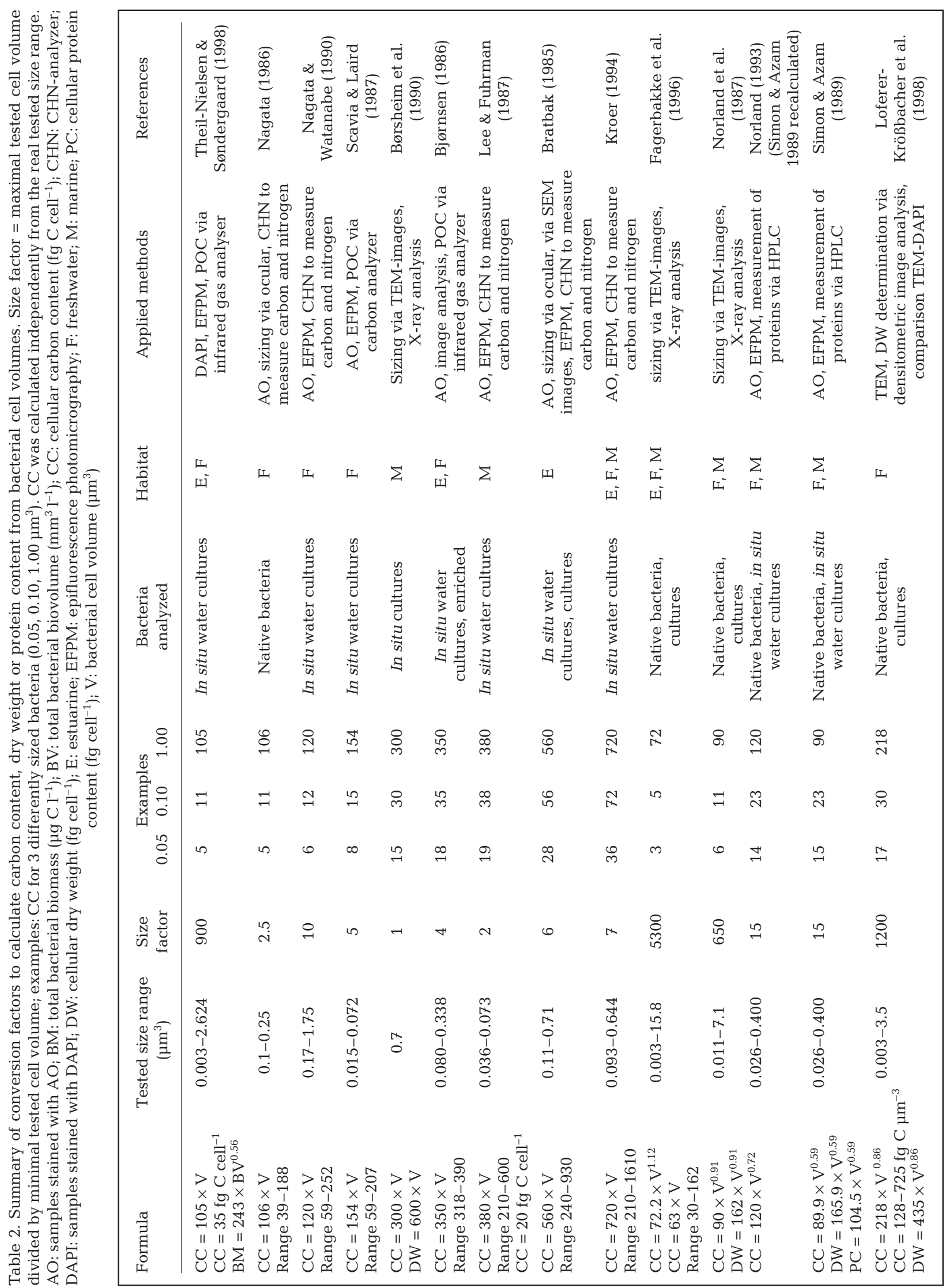


formulae and linear factors provided that these equations were determined for natural bacterial assemblages or enrichments of water samples in situ (Table 2). In total, 5 allometric formulae and 9 linear conversion factors were published during the past 2 decades. Typically, researchers have evaluated or tested their equations for a distinct bacterial size range and many studies caution against an extrapolation to size ranges that had not been investigated. Since 1996, 3 studies also included the smallest size range of bacteria between 0.003 and $0.01 \mu^{3}$ (Table 2). To illustrate the great discrepancies among the equations, we calculated that for a cell volume of $0.05 \mu^{3}$ the estimated CC varied between 3 and $36 \mathrm{fg} \mathrm{C} \mathrm{cell}^{-1}$, with the majority of values ranging between 15 and $20 \mathrm{fg} C$ cell $^{-1}$ (Table 2).

From the allometric formulae, the lowest estimates were found in 2 studies that used X-ray analysis for the determination of bacterial carbon (Norland et al. 1987, Fagerbakke et al. 1996). The highest CC were calculated by using the equation of Loferer-Krößbacher et al. (1998), who applied densitometric image analysis for their measurements. However, Fagerbakke et al. (1996) directly measured the CC of single cells, whereas Loferer-Krößbacher et al. (1998) used TEM to determine the mass and size of single cells. The CC of these cells was assumed to be $50 \%$ of the dry mass. In all other listed studies the bulk dry weight or protein content of a large number of cells was determined (e.g., by $\mathrm{CHN}$ analysis). Interestingly, the allometric formulae yielding the lowest carbon cell ${ }^{-1}$ values had scaling factors around 1 (0.91 and 1.12); i.e., they were in fact linear. Loferer-Krößbacher et al. (1998), who reported the highest published volume-to-carbon conversion factor, explicitly stated that their formula applies only to cell measurements by TEM or based on DAPI staining. The similarity of those different approaches suggests that both size measurements may largely underestimate the real dimensions of living cells. This is a strong indication that conversion factors apply only to the specific staining that they have been developed for and that cell volumes determined from AO stained cells cannot be converted into CC by using a formula developed for DAPI stained bacteria and vice versa.

Comparing the linear conversion factors we found 3 trends. Four studies reported factors around $125 \mathrm{fg} \mathrm{C}$ $\mu \mathrm{m}^{-3}$ (range 105 to 154), another 3 articles give values

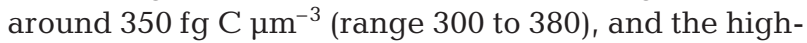

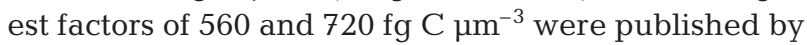
Bratbak (1985) and Kroer (1994). This is probably too high: a simple model calculation shows that spheres consisting of pure lipids, sugars or amino acids would imply a carbon-to-volume conversion factor between

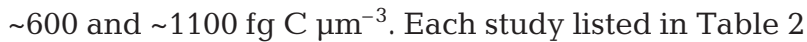
used different combinations of various methods; there- fore, these contrasting results do not seem to be a result of distinct methodologies (Table 2).

The conversion factors of Kroer (1994) and Fagerbakke et al. (1996) resulted in maximal and minimal CC cell ${ }^{-1}$ compared with all other formulae listed in Table 2. Up to a cell size of $0.05 \mathrm{\mu m}^{3}$, the equations suggested by Simon \& Azam (1989), Norland (1993) and Loferer-Krößbacher et al. (1998), and linear con-

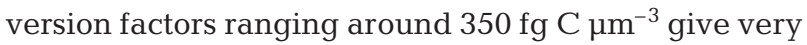
similar results. Since most studies on sizes of natural marine and freshwater bacteria reported cell volumes smaller than $0.1 \mathrm{\mu m}^{3}$, differences among biomass estimates obtained by those various formulae might be relatively small. For higher cell volumes up to $0.2 \mu^{3}$ a linear factor of $300 \mathrm{fg} \mathrm{C} \mathrm{mm}^{-3}$ fits the allometric formula of Loferer-Krößbacher et al. (1998), but calculations for cells larger than $0.2 \mu^{3}$ become remarkably different.

\section{Which volume-to-carbon conversion factor should be used?}

We applied all allometric and linear conversion factors listed in Table 2 to our data sets on DAPI and AO stained samples (Fig. 3A,B). On the basis of the same water samples, but depending on the fluorescent dye and the selected conversion equation, we obtained a minimal total bacterial biomass of $5 \mu \mathrm{g} \mathrm{C} \mathrm{l}^{-1}$ (Fagerbakke et al. 1996) up to a maximal value of $165 \mu \mathrm{g} \mathrm{Cl}^{-1}$ (Kroer 1994) as an average biomass estimate for the vertical profile. This corresponds to a 33-fold difference. Generally, values calculated from abundance and cell volume of DAPI stained bacteria were around half as high as those determined from AO stained samples irrespective of the conversion factor. Consequently, we suggest the application of allometric equations (Table 2). On the one hand, allometric relations between volume and CC were also found for several other planktonic microorganisms, i.e., algae, flagellates and ciliates (Strathmann 1967, Menden-Deuer \& Lessard 2000). On the other hand, most authors presenting linear conversion factors stated that smaller bacteria had higher volume-to-carbon ratios than larger cells (Bratbak 1985, Lee \& Fuhrman 1987, Kroer 1994, Theil-Nielsen \& Søndergaard 1998). To obtain realistic carbon estimates we recommend the use of allometric factors established for the respective fluorescent dye, for instance the equation of LofererKrößbacher et al. (1998) for DAPI stained samples (Fig. 3C) and the formula of Simon \& Azam (1989, recalculated by Norland 1993) for AO stained bacteria (Fig. 3D). Interestingly, the median values of biomass estimates by all 14 equations fit very well with the results obtained by these 2 equations (Fig. 3). Nevertheless, 1 


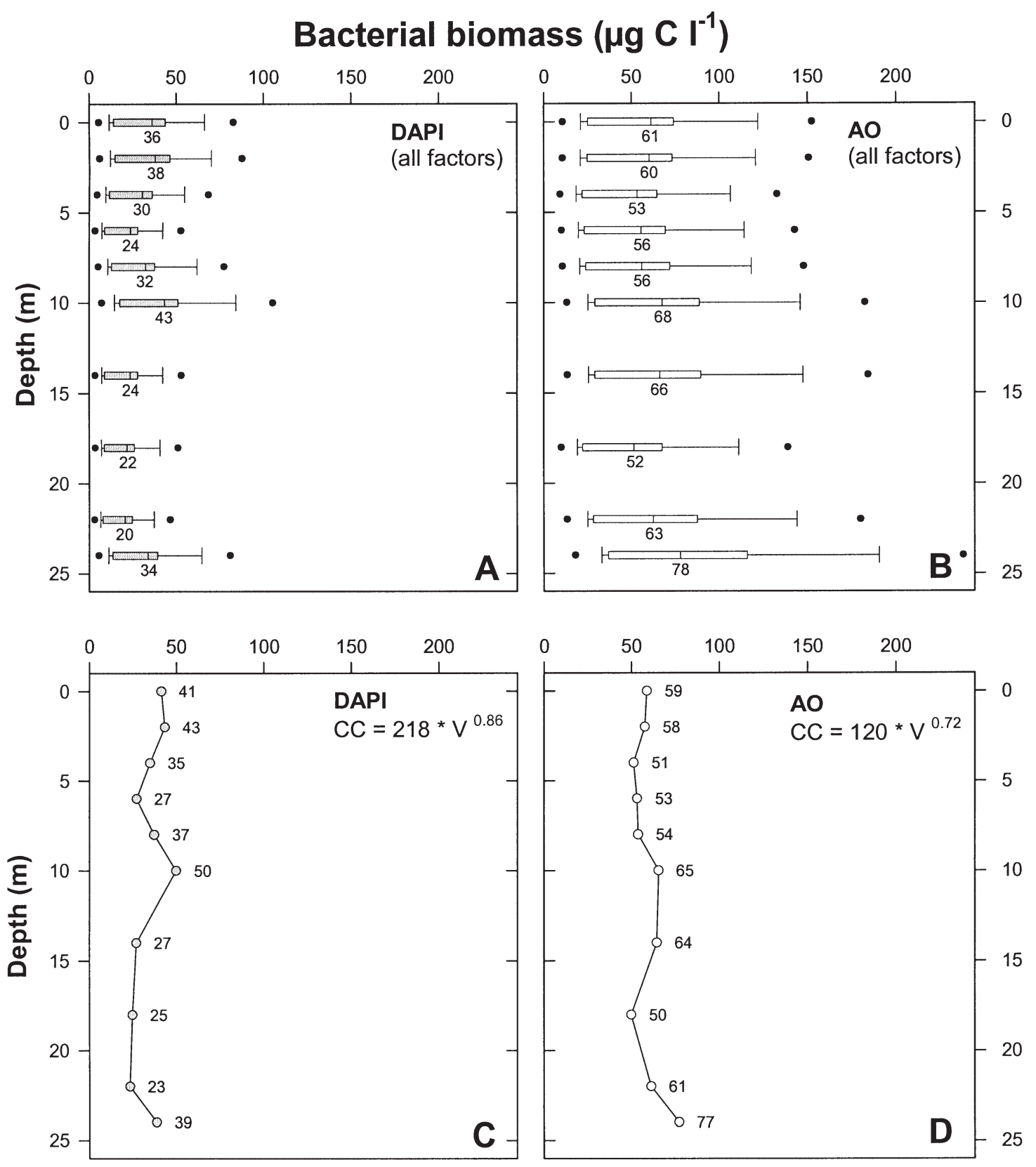

Fig. 3. Vertical distribution of total bacterial biomass $\left(\mu \mathrm{g} \mathrm{Cl}^{-1}\right)$ calculated as the product of abundance and mean cellular carbon content (CC). Bacterial numbers and sizes were determined from DAPI (A, C) and AO (B, D) stained samples. (A) \& (B) CC calculated using all volume-to-carbon conversion factors listed in Table 2. Box: 25th percentile, median and 75th percentile. Whiskers: 10th and 90th percentiles. Black circles: outliers. Values are medians. (C) CC calculated by an allometric conversion formula specifically determined for DAPI stained cells (Loferer-Krößbacher et al. 1998). (D) CC calculated by an allometric formula specifically determined for AO stained cells (Simon \& Azam 1989, recalculated by Norland 1993). For a better comparison with medians in (A) \& (B), besides symbols, values are shown in (C) \& (D). V: Bacterial volume

major difference in the determination of total bacterial biomass remains unresolved by our study. Biomass values based on DAPI stained preparations are only $60 \pm$ $14 \%$ of data determined from samples colored with AO. Consequently, we caution against changing fluorochromes during ongoing studies or comparing data obtained from bacteria stained by different techniques. For example, Sime-Ngando et al. (1991) reported large differences in the bacterial cell volumes from 2 different lakes; however, samples from 1 lake had been stained with DAPI and those from the other lake with AO. 
We must challenge the basic principles of these most frequently used methods to determine $\mathrm{CC}$ of aquatic bacteria. The staining of nucleic acids to calculate the $\mathrm{CC}$ of a whole cell is in fact rather indirect. If the DNA content of bacteria had shown a constant ratio to bacterial dry mass, we could have expect that staining of DNA with DAPI correlates with the mass of bacteria. Instead, a comparison of DNA contents of bacteria from Piburger See with their dry masses showed that there is no linear relation (Fig. 2), but the relation can be more accurately described by an allometric formula: DNA $=0.373 \times$ dry mass ${ }^{0.53}$ (DNA and dry mass in fg, $\mathrm{r}^{2}$ $=0.55, \mathrm{n}=668$, Fig. 2). Consequently, size measurements based mainly on DNA or RNA staining may give different estimates for large and small cells. In addition, we point out the large scatter in these data, indicating highly variable DNA contents of bacteria with nearly identical dry masses (Fig. 2).

\section{CONCLUSIONS}

We suggest that the differences in bacterial cell numbers determined from DAPI and AO stained samples are generally not exorbitantly high. However, DAPI also tends to underestimate the real cell dimensions in freshwater samples (Table 1). At higher bacterial activity, differences between DAPI and AO stained cells decreased. Only those allometric equations should be used that were developed for the same dye, i.e., the formula of Simon \& Azam (1989, recalculated by Norland 1993) for AO and the equation of LofererKrößbacher et al. (1998) for DAPI stained bacteria, respectively. However, it is still questionable whether 1 global conversion factor can cover the wide biological variability of planktonic bacteria (Theil-Nielsen \& Søndergaard 1998).

In a review on comparative analyses in aquatic microbial ecology, Gasol \& Duarte (2000) stated: 'Now, when the ranges of abundances and activities of aquatic microbes are well constrained, the challenge for microbial ecology for the coming decade relies on the assimilation of this wealth of information into theories with predictive power.' On the one hand we share the optimism of the authors. On the other hand, even very widespread, wellestablished methods in microbial ecology, such as the counting and sizing of microorganisms, seem to be greatly affected by technical inaccuracies and researchers' subjectivity. A better choice of appropriate staining protocols and conversion formulae would greatly improve the reliability and the comparability of data collected worldwide. In summary, further research is needed for a standardized determination of total bacterial carbon (and DNA, RNA, protein, phosphorus, nitrogen contents, etc.) during the coming decade.
Acknowledgements. We thank Birgit Sattler for assistance in the laboratory and Stefan Andreatta for critical comments on the manuscript. Guang Gao was a member of the UNESCOCourse 1995, organized by the Limnological Institute of the Austrian Academy of Sciences (Mondsee, Austria), and was funded by a scholarship of the OEAD-EZA. The Austrian Science Fund supported this work (Project FWF P14637-Bio).

\section{LITERATURE CITED}

Bjørnsen PK (1986) Automatic determination of bacterioplankton biomass by image analysis. Appl Environ Microbiol 51:1199-1204

Børsheim KY, Bratbak G, Heldal M (1990) Enumeration and biomass estimation of planktonic bacteria and viruses by transmission electron microscopy. Appl Environ Microbiol 56:352-356

Bratbak G (1985) Bacterial biovolume and biomass estimations. Appl Environ Microbiol 49:1488-1493

Fagerbakke KM, Heldal M, Norland S (1996) Content of carbon, nitrogen, oxygen, sulfur and phosphorus in native aquatic and cultured bacteria. Aquat Microb Ecol 10:15-27

Fry JC (1990) Direct methods and biomass estimation. In: Grigorova R, Norris JR (eds) Methods in microbiology, Vol 22. Academic Press, London, p 41-85

Fuhrman JA, Azam F (1982) Thymidine incorporation as a measure of heterotrophic bacterioplankton production in marine surface waters: evaluation and field results. Mar Biol 66:109-120

Gasol JM, Duarte CM (2000) Comparative analyses in aquatic microbial ecology: how far do they go? FEMS Microbiol Ecol 31:99-106

Gasol JM, Zweifel UL, Peters F, Fuhrman JA, Hagström ^̊ (1999) Significance of size and nucleic acid content heterogeneity as measured by flow cytometry in natural planktonic bacteria. Appl Environ Microbiol 65: 4475-4483

Hobbie JE, Daley RJ, Jasper S (1977) Use of Nucleopore filters for counting bacteria by fluorescence microscopy. Appl Environ Microbiol 33:1225-1228

Karner MB, DeLong EF, Karl DM (2001) Archaeal dominance in the mesopelagic zone of the Pacific Ocean. Nature 409: $507-510$

Kepner RL, Pratt JR (1994) Use of fluorochromes for direct enumeration of total bacteria in environmental samples: past and present. Microbiol Rev 58:603-615

Koike I, Shigemitsu H, Kazuki T, Kazuhiro K (1990) Role of sub-micrometre particles in the ocean. Nature 345: $242-244$

Kroer N (1994) Relationships between biovolume and carbon and nitrogen content of bacterioplankton. FEMS Microbiol Ecol 13:217-224

Lee S, Fuhrman JA (1987) Relationships between biovolume and biomass of naturally derived marine bacterioplankton. Appl Environ Microbiol 53:1298-1303

Loferer-Krößbacher M, Klima J, Psenner R (1998) Determination of bacterial cell dry mass by transmission electron microscopy and densitometric image analysis. Appl Environ Microbiol 64:688-694

Loferer-Krößbacher M, Witzel KP, Psenner R (1999) DNA content of aquatic bacteria measured by densitometric image analysis. Arch Hydrobiol Spec Issues Adv Limnol 54: 185-198

Massana R, Gasol JM, Bjørnsen PK, Blackburn N, Hagström Å, Hietanen S, Hygum BH, Kuparinen J, Pedrós-Alió C (1997) Measurement of bacterial size via image analysis of 
epifluorescence preparations: description of an inexpensive system and solutions to some of the most common problems. Sci Mar 61:397-407

Menden-Deuer S, Lessard EJ (2000) Carbon to volume relationships for dinoflagellates, diatoms, and other protist plankton. Limnol Oceanogr 45:569-579

Nagata T (1986) Carbon and nitrogen content of natural planktonic bacteria. Appl Environ Microbiol 52:28-32

Nagata T, Watanabe Y (1990) Carbon- and nitrogen-tovolume ratios of bacterioplankton grown under different nutritional conditions. Appl Environ Microbiol 56: 1303-1309

Norland S (1993) The relationship between biomass and volume of bacteria. In: Kemp PF, Sherr BF, Sherr EB, Cole JJ (eds) Aquatic microbial ecology. Lewis Publishers, Boca Raton, p 303-307

Norland S, Heldal M, Tumyr O (1987) On the relation between dry matter and volume of bacteria. Microb Ecol 13:95-101

Pechlaner R (1979) Response of the eutrophied Piburger See to reduced external loading and removal of monimolimnic water. Arch Hydrobiol Beih Ergeb Limnol 13:293-305

Pernthaler J, Sattler B, Šimek K, Schwarzenbacher A, Psenner R (1996) Top-down effects on the size-biomass distribution of a freshwater bacterioplankton community. Aquat Microb Ecol 10:255-263

Porter KG, Feig YS (1980) The use of DAPI for identifying and counting aquatic microflora. Limnol Oceanogr 25:943-948

Posch T, Pernthaler J, Alfreider A, Psenner R (1997) Cellspecific respiratory activity of aquatic bacteria studied with the tetrazolium reduction method, Cyto-Clear slides, and image analysis. Appl Environ Microbiol 63:867-873

Scavia D, Laird GA (1987) Bacterioplankton in Lake Michigan: dynamics, controls, and significance to carbon flux.

Editorial responsibility: Karel Šimek,

České Budějovice, Czech Republic
Limnol Oceanogr 32:1017-1033

Sieracki ME, Viles CL (1992) Distributions and fluorochromestaining properties of sub-micrometer particles and bacteria in the North Atlantic. Deep Sea Res 39:1919-1929

Sieracki ME, Johnson PW, Sieburth JM (1985) Detection, enumeration, and sizing of planktonic bacteria by image-analyzed epifluorescence microscopy. Appl Environ Microbiol 49:799-810

Sime-Ngando T, Bourdier G, Amblard C, Pinel-Alloul B (1991) Short-term variations in specific biovolumes of different bacterial forms in aquatic ecosystems. Microb Ecol 21:211-226

Simon M, Azam F (1989) Protein content and protein synthesis rates of planktonic marine bacteria. Mar Ecol Prog Ser 51:201-213

Sommaruga R, Psenner R (1995) Trophic interactions within the microbial food web in Piburger See (Austria). Arch Hydrobiol 132:257-278

Sommaruga R, Krössbacher M, Salvenmoser W, Catalan J, Psenner R (1995) Presence of large virus-like particles in a eutrophic reservoir. Aquat Microb Ecol 9:305-308

Strathmann RR (1967) Estimating the organic carbon content of phytoplankton from cell volume or plasma volume. Limnol Oceanogr 12:411-418

Suzuki MT, Sherr EB, Sherr BF (1993) DAPI direct counting underestimates bacterial abundances and average cell size compared to AO direct counting. Limnol Oceanogr 38:1566-1570

Theil-Nielsen J, Søndergaard M (1998) Bacterial carbon biomass calculated from biovolumes. Arch Hydrobiol 141: 195-207

Zweifel UL, Hagström $\AA$ (1995) Total counts of marine bacteria include a large fraction of non-nucleoid-containing bacteria (ghosts). Appl Environ Microbiol 61:2180-2185

Submitted: January 30, 2001; Accepted: May 9, 2001

Proofs received from author(s): July 5, 2001 